\title{
SWIFT beginnings - exploring the effectiveness and transformative character of a Summer Writing Institute For Teachers (SWIFT)
}

\section{Alison Farrell \& MUA SWIFT}

To cite this article: Alison Farrell \& MUA SWIFT (2019) SWIFT beginnings - exploring the effectiveness and transformative character of a Summer Writing Institute For Teachers (SWIFT), Innovations in Education and Teaching International, 56:2, 229-238, DOI:

10.1080/14703297.2017.1412833

To link to this article: https://doi.org/10.1080/14703297.2017.1412833

曲 Published online: 12 Dec 2017.

Submit your article to this journal $\llbracket$

Џ Article views: 165

Q View related articles ¿

View Crossmark data 〔 


\title{
SWIFT beginnings - exploring the effectiveness and transformative character of a Summer Writing Institute For Teachers (SWIFT)
}

\author{
Alison Farrell and MUA SWIFT \\ Centre for Teaching and Learning, School of Education, Maynooth University, Maynooth, Ireland
}

\begin{abstract}
The purpose of this article is to describe, examine, and make a case for the value of a Continuing Professional Development week-long summer institute offered to teachers from across the education continuum - from early childhood, through primary, secondary, further and higher education. At the institute participants could meet, learn and share good practice about their own writing and the teaching of writing. The institute was inspired by the United States National Writing Project model and was designed by staff of the Maynooth University Writing Centre, in partnership with the Bay Area Writing Project, University of California Berkeley, and in consultation with a range of Irish teaching and learning networks. This paper presents the background to and rationale for the institute, considers its effectiveness in terms of the model, the'personality' and the impact of the summer institute, and suggests how the summer institute is transformative for participants.
\end{abstract}

\section{KEYWORDS}

Writing; national writing project; continuing professional development; transformative learning; teaching approaches

\section{Introduction}

Revisiting this article, armed with the encouraging, insightful and generous comments of two reviewers, perfectly reinforces for us just how difficult and challenging it is sometimes, or indeed often, to write. We would have baulked at revising this work were it not for the fact that we are convinced that writing matters and that the pilot Summer Writing Institute For Teachers (SWIFT) which we report on here supports writers in effective and potentially transformative ways. In order to explain why SWIFT was a success, this article begins by stating why writing and writing support matters to us. From this broad base, we refine our thinking to consider the responsibility we have, as members of the Academy, to support writers and to advocate for writing development. We follow this with our rationale for, and experience of, establishing SWIFT in July 2014. We use the participant data we gathered to report on the extent to which we achieved the goals implicit in the rationale. In our discussion, we remind readers of how our work connects with broader important ideas around writing and we use the work of Ron Barnett in particular to help us to understand why the SWIFT model was successful. 


\section{Why writing matters - the 'Ladybird' version}

As writers, who have regular dalliances with academic texts, we find ourselves reaching for one of those catch-alls that we have in our portfolio which begins 'it is beyond the scope of this article to ...' Regretfully, it is truly beyond the scope of this modest article to explore in any comprehensive manner why writing matters within our formal education settings. And yet, as our case rests on this statement, a whistle-stop through this core idea is presented here first.

Our university, and indeed the national education sectors, across primary, post primary, further and higher education, consistently reinforce the belief that writing matters. This emphasis surely stems from traditions around both formative and summative written assessments, but it is also part of a contemporary culture of mass authorship where writing is dominant. Deborah Brandt considers this in her recent publication The Rise of Writing. Redefining Mass Literacy where she remarks of writing'as a mass daily experience .... [where] texts serve as a chief means of production and a chief output of production' $(2015$, p. 3). Brandt goes on to suggest that, 'For perhaps the first time in the history of mass literacy, writing seems to be eclipsing reading as the literate experience of consequence' (2015, p. 3). A similar message is conveyed by the National Writing Project (NWP) in the United States who note that writing is 'essential' as the 'currency of the new workplace and global economy', as well as helping us to 'convey ideas, solve problems, and understand our changing world' (National Writing Project [NWP], 2016). Universities as literacy communities conspicuously demonstrate their commitment to writing in the substantial amount of university time and resources that goes into writing of one form or another. Predictably, this involves academic writing across this community, from that of emergent student scholars to eminent professors, but it also includes all kinds of other writing. Lea and Stierer (2011) note that academic identity can involve 'becoming adept at engaging in a range of written genres which are often far removed from ... traditional academic writing' (p. 615). In unpublished on-campus research that we completed in academic year 2012-2013, we found that our students also write a great deal outside of academic genres including journaling, blogging, emailing, texting, writing poetry and fiction, writing in social media etc. Writing continues to be essential to the scholarly and everyday lives of our university community and, while the composition media may change and extend, we predict no immediate diminution in terms of text production and composition more broadly in education settings. On the contrary, some quarters are calling for more writing citing that undergraduates do not write enough, nor do they write sufficiently long pieces (Arum \& Roksa, 2011).

In addition to the prevalence of writing in modes of assessment, writing has other functions which contribute to it being an essential element of the education experience. Primary amongst these is how writing facilitates us in making and finding meaning. When we work with student writers we assert that writing aids meaning making; it is a key component of critical thinking and it can help us to learn (Adler-Kassner \&Wardle, 2016; Emig, 1977; McLeod, 2012; Myers Zawacki \& Rogers, 2012; Riedner, O'Sullivan, \& Farrell, 2015; Thaiss, Brauer, Carlino, Ganobcsik-Williams, \& Sinha, 2012; WAC Clearinghouse Publications \& Series, 19972017). In addition, writing can help us to learn more about ourselves and about being human: it can help us to find meaning in our lives. This desire to make and find meaning drives a great deal of our work and as such, it underpinned our goals in initiating SWIFT. This meaning making/finding approach moves education beyond it being the cog in the knowledge 
economy wheel, to an interpretation of education as transformative, what Barnett calls knowing and becoming, and where he makes, what we consider desirable links between 'knowledge and student being and becoming' (2009, p. 429). He suggests, in what we adopt here as a working definition of transformative learning, that 'coming to know the world is uplifting; the process of knowing brings forward personally worthwhile attributes' (p. 433).

Accepting writing's essential function in meaning making and finding, knowing and becoming, we assert that in education supporting writing matters. Because'all writers always have more to learn about writing' (Rose, 2016, p. 59), and because'learning to write effectively requires different kinds of practice, time, and effort' (Blake Yancey, 2016, p. 64) when we work with writers we help them to develop effective writing processes and to foster writing transfer which we hope will facilitate flexibility, agility and cross genre competence (Anson \& Moore, 2016; Farrell \& Tighe-Mooney, 2015; Moore \& Bass, 2017; Yancey, Robertson, \& Taczak, 2014). In this regard, we are concerned certainly with text production but also with writerly identity, acknowledging Thomson and Kamler's belief that these two things cannot be disentangled: 'Text work and identity work are inseparable' (2016, p. 21). In addition, we believe that writing is an essential part of democracy and civic engagement (Adler-Kassner \& Harrington, 2002; Duffy, 2017; Kahn \& Lee, 2010). Moreover, we see writing as a social act where we aim not only to communicate but also to connect with each other. We seek joy in our writing, where possible, and aim to celebrate writing on campus and beyond.

\section{Rationale for SWIFT}

Building, thus, on the belief of the centrality of writing to the learning experience, we sought to explore how we could support writers in formal education settings within and beyond our institution; under legislation, universities in Ireland have a statutory requirement to promote learning in society generally (Government of Ireland, 1997). One gap in local and national provision which we identified, and subsequently pursued in SWIFT, was the lack of discussion about writing across the education levels. We believed that greater communication between teachers across these levels, through a shared continuing professional development (CPD) experience, would be of value to all participants, would improve knowledge and understanding of each others' settings, would enhance our understanding of how best to support writers, and might contribute more broadly to positive change and opportunities for participant transformative learning. In our scoping of this idea we discovered that such an approach existed in the United States and had done so for more than forty years.

\section{The NWP}

The NWP was established in the United States in 1974 by James Gray (2000) and colleagues at the University of California, Berkeley as a university-based programme for teachers from early childhood through to second level - 'K-16' - with the founding site being the Bay Area Writing Project (BAWP). As noted on the NWP website, Grey was motivated to create 'a different form of professional development for teachers, one that made central the knowledge, leadership, and best practices of effective teachers, and that promoted the sharing of that knowledge with other teachers' (NWP, 2016). Since its establishment over forty years ago, the NWP has articulated its role, developed its model and expanded its number of sites. 
The NWP asserts that writing is 'essential to communication, learning, and citizenship' (NWP, 2016). The essence of the NWP is articulated in five core principles. These emphasise, amongst other ideas, that teachers can be agents of reform, that writing can be taught using a range of approaches, and that teachers should have the opportunity to demonstrate, share and debate as part of 'a reflective and informed community of practice' (NWP, 2016). The cornerstone of the NWP sites' work is the hosting of an invitational summer institute. This summer institute involves teachers from across all education levels meeting together to share good practice, to learn, to explore research and to write.

\section{Rationale for piloting a NWP type summer writing institute in [Ireland]}

From our examination of the NWP model, and given the success it had achieved in the US, we believed that it could be repurposed to serve local cohorts. We were drawn to the model because of its alignment with our thinking and ethos, and our institutional and sectoral commitments (Farrell \& Tighe-Mooney, 2015). In addition, we wished to learn more about how we might best support teachers of writing and writers on campus; centralised support for writing in our university is currently provided under the auspices of the Centre for Teaching and Learning, hence, it is unsurprising that our work is influenced by the substantial literature in this area that seeks to value and support colleagues as writers (Bolton \& Rowland, 2014; Elbow \& Belanoff, 2003; Geller \& Eodice, 2013; Kitchin \& Fuller, 2005; O'Farrell \& Fitzmaurice, 2013; Sword, 2012; Wisker, 2013). Our research into the NWP highlighted the success it has had in the developing of best practices, building of local, state-wide and national writing communities and leaders, in providing CPD opportunities for teachers of writing and in improving students' writing (St John \& Stokes, 2012; NWP, 2010; Stokes, 2011). We were also encouraged to pilot a NWP model by the research that demonstrated that outside of the US, there has been interest and engagement in the NWP model, for example in Malta, Norway, New Zealand and the United Kingdom (Malta Writing Project (MWP), 2015; Trondheim Writing Project, 2015; Locke, Whitehead, Dix, \& Cawkwell, 2011; Andrews, 2008; National Writing Project UK (NWP-UK), 2015; Smith \& Wrigley, 2016).

\section{Establishing SWIFT}

Planning for our institute involved consulting with colleagues and the seeking of funding which allowed us to build on an established connection with the Bay Area Writing Project and to invite both the director and the co-director of their summer writing institute to share with us in the facilitation of our first institute. Though the US NWP summer institute is generally 3-4 weeks in duration, from our consultation and experience in the sector in Ireland we considered that a week-long event might be more appropriate; New Zealand colleagues made a similar adjustment in their writing workshop (Locke et al., 2011, p. 278). Three NWP elements which we deemed essential for the week were participant demonstrations (teaching), time for personal writing, and writing groups/author's chair. The final institute programme incorporated prepared demonstrations from eight of the 18 participants, guest contributions from writers and teachers, personal writing time, a writing group slot, daily logging and journaling, and a celebratory author's chair on the final day. In terms of representation from across the sectors, the 18 participants were split as follows: four from higher education, two from further education, eight from post-primary, two from primary education, 
and two teachers from outside of the formal education sectors: one of the further education participants was also an early childhood educator.

As facilitators, we hoped to fulfil the goals of the SWIFT rationale as evaluated through positive participant reactions, reporting of participant learning and participant commitment to application of learning post institute i.e. the achievement of three each of Kirkpatrick's (Kirkpatrick \& Kayser Kirkpatrick, 2016) and Guskey's (2002) evaluation levels (reaction, learning, and behaviour/use of new knowledge and skills). We also hoped that SWIFT would be transformative in terms of contributing to positive personal and professional change.

\section{Methodology}

This element of our research into SWIFT 2014 set out to assess whether SWIFT had achieved the purposes for which it had been designed. As such, this article is based on data which was gathered in a short, post institute evaluation which all 18 colleagues completed in hard copy at the end of the week before leaving the institute venue. We kept our evaluation deliberately broad and asked for open text feedback from participants in response to four questions, namely:

(1) What worked this week? Strengths?

(2) What would you change?

(3) Can you name three or more things that you are taking from this week that will impact on your practice in your education setting?

(4) What do you want to do next?

We approached the data using thematic analysis in order to identify, analyse and report patterns/themes (Braun \& Clarke, 2006, p. 79). As such we worked through the phases of becoming familiar with the data (reading and re-reading), 'generating initial codes', and 'searching for ... [and] reviewing themes' (p. 87). This process led us to'defining and naming themes' which we include in our reporting here (p. 87).

\section{Findings}

In excess of twenty initial themes were coded from the data obtained across the four questions. These themes were distilled to three candidate themes, reported here.

The first theme we identified was 'the effectiveness of the model' which included elements about SWIFT such as its structured nature, the variety and richness within the content/ideas and the presentation of same, the mix of backgrounds of participants, the space for personal writing, the supportive and constructive nature of the advocated approaches, the time for informal networking and exchange over breaks and lunch, and the research-informed nature of the work. Specifically participants noted:

...huge amount of organisation and planning ... The diverse ... range of backgrounds

The demos were so varied and insightful ...

The cross-sectoral mix really worked and gave all of us, I think, a deeper appreciation of the work that we do as educators in the different sectors.

The majority of participants suggested that they would change nothing fundamentally about the week, that they had learned a great deal, and that they intended applying that learning 
when they returned to their settings. This learning included: modelling writing, more writing opportunities, including fun in learning, journaling, writers groups, several different approaches/ideas to teaching/supporting writing, strategies for giving feedback and responding to texts, using multi-media in writing, collaborative writing approaches etc.

The second theme which was identified from the data was'the personality of the institute'. All participants remarked on the tone of the institute and its collective 'personal' qualities as strengths. Participants remarked, that 'The integrity ... of approach is crucial' and that 'It was a week of good deep, earthy, sensual, delicious, soulful meaning ...' They noted the richness of the institute captured in statements such as 'So many voices, so much creativity, such commitment and passion.' They described the institute using words such as 'safe,',informal','open', 'fresh', 'unobtrusive,',positive,',stimulating,',wonderful','life-affirming,', 'refreshing', 'brilliant,',scintillating', 'fruitful,' 'profound', 'collaborative', 'friendly'.

The third theme which the data suggested was that of 'experience and effect'. As a group, participants felt a sense of belonging: they noted they felt 'welcome,' 'part of something important that mattered'; they felt 'inspired,' 'enthusiastic','engaged', 'a willingness to share', 'no sense of competition', 'an attitude of caring and nurturing'. Participants also noted changes or shifts in their sense of self, as writers and/or teachers. These included a sense of renewal about being a writer and being a teacher, energy, confidence, empowerment, enrichment, passion, inspiration, collegiality, reflection and creativity. They articulated this in powerful statements such as'I am a writer' and 'It confirmed that much of my practice as a teacher is worthwhile and has real purpose and value - affirmation is often hard to find in the day to day life of a teacher'. One participant noted: 'Less sense of isolation'. Others reflected beyond their own experience to future potential impacts:

A sense that I could and should begin to take on leadership roles to affect good change within the education environment and system.

Desire to embrace change for the better in education and to share/demonstrate this feeling in my place of work.

Practically, participants noted that they wanted to not only apply their learning in their settings, but also to cascade it to other colleagues. They also wanted to keep in touch with each other, and to research, read and write more.

The following quotations give a flavour of, but regretfully only inadequately capture, the overall comments of the group which were overwhelming positive and which reflect the three themes from the data:

As a teacher, writer and researcher everything came together for me. It has been the best professional week of my life, and it also nurtured me as a creative writer.

Everything. From start to finish this has been the most amazing experience ... there was no down at all for me.

I loved the energy of the week, the fact that each and every one of us engaged wholeheartedly in the project. I loved that it was an open enquiry into what we do when we write and teach writing. I even loved the disagreements ... I loved the daring and courage of people.

It was one of the best educational experiences of my life.

\section{Discussion}

From the analysis of the data we can confidently say the following: 
- that all colleagues had a positive reaction to participating in the SWIFT

- that all colleagues learned something new about themselves as writers and about supporting writers

- that all colleagues intended to apply their learning in their settings when they returned to them, thus they intended to change their behaviour as writers and teachers.

The data suggest that our repurposed version of the NWP was a success in terms of achieving the goals for which it was intended; it provided a collaborative non-judgemental approach, with rich conversations, generous sharing, committed interaction and what participants considered a refreshing openness in terms of teaching and learning possibilities. In addition, the summer institute itself is a unique contribution to the Irish education landscape in providing an occasion for teachers across the sector to meet and share practice on a common area of concern. As such it addresses that existing gap and contributes to the fulfilment of our statutory obligation in terms of outreach.

While we could also connect the positive outcomes of SWIFT to literature around other successful writing interventions, including writing groups and writers' retreats, (Grant, 2006; Murray, 2015; Smith \&Wrigley, 2016), in order to decipher more precisely the transformative nature of SWIFT we turn again to Barnett, specifically, and his proposition that 'the very process of coming to know ... has virtuous possibilities, independently of any endpoint that the student may reach' $(2009$, p. 437). Barnett suggests that knowing and becoming involves the nurturing of 'epistemic virtues', by which he means both dispositions and qualities, where the former includes a will to learn, engage, listen, explore and keep going, and the latter 'courage, resilience, carefulness, integrity, self-discipline, restraint, respect for others, openness, generosity, authenticity' (p. 434). He develops his argument to suggest if these kinds of epistemic virtues'are to be fashioned, then curricula and pedagogy have to be more than a matter of an encounter with knowledge' (p. 438). And this is SWIFT; SWIFT is a great deal more than an encounter with knowledge. It has the sort of curriculum/model that Barnett advocates in that it is demanding, offers contrasting insights, requires a continual presence and commitment and contains 'sufficient space and spaces, such that 'authenticity' and 'integrity' are likely to unfold' (emphasis in original, p.438). With regards pedagogies, SWIFT again echoes Barnett where it requires engagement with others, is encouraging and enthusing, requires participants to 'usher forth their 'will to learn", and where it requires participants 'to give of themselves and be active in and towards the situations that they find themselves in ...' (emphasis in original, p. 438). The model and character of SWIFT, as designed, facilitated, experienced and described by all participants, encapsulates all of Barnett's proposed curricular and pedagogical qualities for knowing and becoming, that is, for transformative learning.

\section{Further}

We recognise that this article draws on limited data from a small scale project. However, since SWIFT 2014, we have run a writing institute every summer and post each iteration the data we gather highlight that the experience is consistently transformative for participants. Similarly, we find that the effects of the institute extend well beyond the week into positive changes in learning and teaching, and renewal in being for participants as teachers and writers; we believe that this translates into enhanced learning experiences for our students, 
and ongoing fruitful dialogue across the sector. Though there are resource implications to running the week, they are not substantial and once the model is established it can be replicated each summer without the need for any radical reinvention. One challenge we have encountered is accommodating the demand which we have from those wishing to attend; we are always over subscribed and have to make difficult decisions about who can participate.

Reflecting on the initiative, we are encouraged to continue to provide a summer writing institute in fulfilment of the rationale outlined earlier in this article. We firmly believe that writing matters and that the summer institute is a highly effective, practical and joyful intervention for writers and those teaching writing.

\section{Acknowledgements}

We gratefully acknowledge support from Irish National Forum for the Enhancement of Teaching and Learning in Higher Education, as an element of a collaborative bid by the Irish Network for the Enhancement of Writing (INEW), which helped to fund the summer institute in July 2014.

\section{Disclosure statement}

No potential conflict of interest was reported by the authors.

\section{Funding}

This work was supported by National Forum for the Enhancement of Teaching and Learning in Higher Education.

\section{Notes on contributors}

Alison Farrell is Teaching Development Officer in the Centre for Teaching and Learning, Maynooth University where she is also Head of the University's Writing Centre. She is the founder of the Summer Writing Institute For Teachers (SWIFT).

MUA SWIFT is the authorial persona of the SWIFT 2014 participants. We are Donna Callan, Dan Campion, Christina Clarke, Eileen Condon, Josephine Donohoe, Louise Donohoe, Mary Galligan, Claire Heylin, Kristin Land, Mary Lowry, Niamh Mac Alister, Ferdia MacAnna, Deirdre McClay, Chris McCormack, Clair Ni Aonghusa, Aingeal Ni Mhurchu, Margaret O'Brien, Ann O'Regan, Greta Vollmer and Patricia Wall.

\section{References}

Adler-Kassner, L., \& Harrington, S. (2002). Basic writing as a political act: Public conversations about writing and literacies. New York, NY: Hampton Press.

Adler-Kassner, L. \& Wardle, E. (Eds.). (2016). Naming what we know. Threshold concepts of writing studies. Classroom edition. Logan: Utah State University Press.

Andrews, R. (2008). The case for a National Writing Project for teachers. CfBT Education Trust. Retrieved from http://cdn.cfbt.com/ /media/cfbtcorporate/files/research/2008/r-the-case-for-a-nationalwriting-project-for-teachers-2008.pdf

Anson, C. M., \& Moore, J. L. (Eds.). (2016). Critical transitions: Writing and the question of transfer. Perspectives on Writing, Fort Collins: The WAC Clearinghouse and University Press of Colorado.

Arum, R., \& Roksa, J. (2011). Academically adrift. Limited learning on college campuses. Chicago, IL: The University of Chicago Press. 
Barnett, R. (2009). Knowing and becoming in the higher education curriculum. Studies in Higher Education, 34, 429-440.

Blake Yancey, K. (2016). Learning to write effectively requires different kinds of practice, time, and effort. In L. Adler-Kassner \& E. Wardle (Eds.), Naming what we know. Threshold concepts of writing studies. Classroom edition (pp. 64-65). Logan: Utah State University Press.

Bolton, G., \& Rowland, S. (2014). Inspirational writing for academic publication. London: SAGE Publications. Brandt, D. (2015). The rise of writing. Redefining mass literacy. Cambridge: Cambridge University Press. Braun, V., \& Clarke, V. (2006). Using thematic analysis in psychology. Qualitative Research in Psychology, 3, 77-101.

Duffy, J. (2017). The good writer: Virtue ethics and the teaching of writing. College English, 79, 229-250.

Elbow, P., \& Belanoff, P. (2003). Being a writer. A community of writers revisited. New York, NY: McGrawHill Higher Education.

Emig, J. (1977). Writing as a mode of learning. College Composition and Communication, 28, 122-128.

Farrell, A., \& Tighe-Mooney, S. (2015). Recall, recognise, re-invent: The value of facilitating writing transfer in the writing centre setting. Journal of Academic Writing, 5, 29-42.

Geller, A. E. \& Eodice, M. (Eds.). (2013). Working with faculty writers. Logan: Utah State University Press. Government of Ireland. (1997). Universities act, 1997. Dublin: Dublin Stationery Office.

Grant, B. (2006). Writing in the company of other women: Exceeding the boundaries. Studies in Higher Education, 31, 483-495.

Gray, J. (2000). Teachers at the center: A memoir of the early years of the National Writing Project. The Quarterly, Fall, 22, 417-423.

Guskey, T. R. (2002). Does it make a difference? Evaluating professional development. Educational Leadership. Redesigning Professional Development, 59, 45-51.

Kahn, S., \& Lee, J. (2010). Activism and rhetoric. Theories and contexts for political engagement. Abington: Taylor \& Francis eBooks.

Kirkpatrick, J., \& Kayser Kirkpatrick, W. (2016). Kirkpatrick's four levels of training evaluation. Alexandria: ATD Press.

Kitchin, R., \& Fuller, D. (2005). The academic's guide to publishing. London: SAGE Publications.

Lea, M. R., \& Stierer, B. (2011). Changing academic identities in changing academic workplaces: Learning from academics' everyday professional writing practices. Teaching in Higher Education, 16, 605-616.

Locke, T., Whitehead, D., Dix, S., \& Cawkwell, G. (2011). New Zealand teachers respond to the 'National Writing Project' experience. Teacher Development, 15, 273-291.

Malta Writing Project (MWP). (2015). Retrieved from http://mwp.skola.edu.mt

McLeod, S. (2012). "The pedagogy of writing across the curriculum."In T. Myers Zawacki \& P. M. Rogers (Eds.), Writing across the curriculum: A critical sourcebook (pp. 149-164). Boston, MA: Bedford/St. Martin's.

Moore, J. L., \& Bass, R. (2017). Understanding writing transfer. Implications for transformative student learning in higher education. Sterling: Stylus Publishing.

Murray, R. (2015). Writing in social spaces: A social processes approach to academic writing. London: Routledge \& The Society for Research into Higher Education.

Myers Zawacki, T. \& Rogers, P. M. (Eds.). (2012). Writing across the curriculum: A critical sourcebook. Boston, MA: Bedford/St. Martin's.

National Writing Project (NWP). (2010). Research Brief No 2. Retrieved from http://www.nwp.org/cs/ public/download/nwp_file/14004/FINAL_2010_Research_Brief.pdf

National Writing Project (NWP). (2016). Retrieved from http://www.nwp.org

National Writing Project UK (NWP-UK). (2015). Retrieved from http://www.nwp.org.uk

O'Farrell, C., \& Fitzmaurice, M. (2013). Academic developers using narrative to support our professional development. Innovations in Education and Teaching International, 50, 227-237.

Riedner, R., O'Sullivan, I., \& Farrell, A. (2015). An introduction to Writing In the Disciplines (WID) curriculum. Maynooth: All Ireland Society for Higher Education/Irish Network for the Enhancement of Writing.

Rose, S. (2016). All writers have more to learn. In L. Adler-Kassner, \& E. Wardle (Eds.), Naming what we know. Threshold concepts of writing studies. Classroom edition (pp. 59-61). Logan: Utah State University Press. 
Smith, J., \& Wrigley, S. (2016). Introducing teachers' writing groups. Exploring the theory and practice. Abingdon: Routledge.

St John, M., \& Stokes, L. (2012). The power of the NWP as it makes an evolutionary leap forward. An evaluator's perspective. Inverness Research. Retrieved from http://inverness-research.org/reports/ slides_nwp/2012-03_Slds_NWP-SpringMtg-final_050112.pdf

Stokes, L. (2011). The enduring quality and value of the national writing project's teacher development institutes: Teachers' assessments of NWP contributions to their classroom practice and development as leaders. Retrieved from http://www.inverness-research.org/reports/2011-11-Rpt-NWP-NWP-SurveyTeacherlnst-Final.pdf

Sword, H. (2012). Stylish academic writing. Cambridge: Harvard University Press.

Thaiss, C., Brauer, G., Carlino, P., Ganobcsik-Williams, L., \& Sinha, A. (2012). Writing programs worldwide: Profiles of academic writing in many places. Fort Collins, CO: The WAC Clearinghouse.

Thomson, P., \& Kamler, B. (2016). Detox your writing: Strategies for doctoral researchers. London: Routledge/Taylor and Francis Group.

Trondheim Writing Project. (2015). Retrieved from http://www.skrivesenteret.no/om-oss/english/ WAC Clearinghouse Publications \& Series. (1997-2017). Retrieved from https://wac.colostate.edu Wisker, G. (2013). Articulate - Academic writing, refereeing, editing and publishing our work in learning, teaching and educational development. Innovations in Education and Teaching International, 50, 344-356.

Yancey, K., Robertson, L., \& Taczak, K. (2014). Writing across contexts: Transfer, composition, and sites of writing. Logan: Utah State University Press. 